\title{
DAKWAH UNTUK PEMBERDAYAAN PEREMPUAN DALAM PEMBANGUNAN PERTANIAN DI PERDESAAN
}

\author{
Mar'atus Sholehah \\ Mahasiswa Pasca Sarjana UIN Walisongo \\ Email: Zhumarzhu@yahoo.co.id
}

\begin{abstract}
Abtract
This article is aimed at the description of many thoughts and ideas of da'wa about the role and the opportunity of woman who work in agriculture and repositioning the strategy of gender within the rural agricultural development policies. The double role of women is clearly indicating the importance of the double sources of income for a household. Women potentials, either as a housewife or as an individual of agricultural worker is the important factor to determine the success of gender strategy. The empowerment is suggested through applied and innovative technology, protection of working woman, improvement of training and extension activities, enhancement of regulations, facility support, increasing wage rate, and household industry skill development. Job opportunity is suggested to balance between male and female and encourage woman to participate in various development activities. With this, the gender strategy would improve household welfare in rural areas.
\end{abstract}

$* * * *$

Artikel ini ditujukan untuk mendeskripsikan tentang pemikiran dan gagasan dakwah berdasarkan teori tentang peran dan peluang perempuan yang bekerja di bidang pertanian dan reposisi strategi gender dalam kebijakan pembangunan pertanian pedesaan. Peran ganda perempuan jelas menunjukkan pentingnya sumber penghasilan ganda untuk sebuah rumah tangga. Potensi perempuan, baik sebagai ibu rumah tangga atau sebagai individu pekerja pertanian merupakan faktor penting untuk menentukan keberhasilan strategi gender. Pemberdayaan disarankan melalui teknologi terapan dan inovatif, perlindungan perempuan pekerja, peningkatan pelatihan dan kegiatan penyuluhan, peningkatan regulasi, dukungan fasilitas, peningkatan tingkat upah, dan pengembangan keterampilan industri rumah tangga. Kesempatan kerja disarankan untuk menyeimbangkan antara pria dan perempuan dan mendorong perempuan untuk berpartisipasi dalam berbagai kegiatan pengembangan. Dengan ini, strategi dakwah terhadap perempuan akan meningkatkan kesejahteraan rumah tangga di daerah pedesaan.

Kata Kunci: Dakwah untuk Pemberdayaan Perempuan, Pembangunan Pertanian 


\section{A. PENDAHULUAN}

Paradigma modernisasi dalam pelaksanaan pembangunan pertanian yang mengutamakan prinsip efisiensi, secara nyata telah mengakibatkan terjadinya berbagai perubahan pada masyarakat petani, baik struktur sosial, budaya dan politik, maupun struktur ekonomi di perdesaan. Pembangunan pertanian di pedesaan tersebut telah menyebabkan pertumbuhan perekonomian, namun belum sepenuhnya diimbangi peningkatan pendapatan rumah tangga petani seperti yang diharapkan.Hal ini disebabkan laju pergeseran ekonomi sektoral yang lebih cepat dibanding laju pergeseran tenaga kerja; dimana titik balik untuk aktivitas ekonomi di Indonesia lebih dulu tercapai dibanding titik balik penggunaan tenaga kerja. ${ }^{1}$

Perubahan yang terjadi terutama berkaitan erat dengan pola penguasaan dan pengusahaan lahan, struktur kesempatan kerja dan berusaha serta pola hubungan kerja; yang akhirnya bermuara pada struktur pendapatanpetani di perdesaan. ${ }^{2}$ Beberapa penelitian memperkirakan bahwa lebih dari 23.100 ha lahan di Jawa telah terkonversi ke penggunaan di luar pertanian. ${ }^{3}$ Tingginya kebutuhan akan lahan sebagai dampak pesatnya industrialisasi dan kebutuhan prasarana ekonomi serta pemukiman, mengakibatkan lahan pertanian produktif semakin menyempit, sementara pencetakan lahan pertanian baru belum sebanding dengan kebutuhan.

Sebagai negara agraris, aktivitas pertanian masih menjadi sumber mata pencaharian mayoritas angkatan kerja di Indonesia. Sektor pertanian diharapkan berperan dalam meningkatkan pendapatan dan taraf hidup petani, pertumbuhan kesempatan kerja danberusaha, meningkatkan gizi dan ketahanan pangan rumah tangga, serta mengentaskan kemiskinan di perdesaan. Meski demikian, sektor pertanian dan lapangan kerja primer mengindikasikan keterbatasan penyerapan tenaga kerja perempuan. Apalagi masuknya teknologi pertanian dan timbulnya berbagai pranata baruyang mengatur hubungan antar pemilik lahandan penyakap, penyewa, dan buruh tani, menjadikan semakin terdesaknya posisi perempuan tani.

Keberhasilan pembangunan pertanian yang belum optimal, salah satunya ditenggaraiakibat belum optimalnya peningkatan kualitas sumberdaya manusia (SDM), sehingga mempengaruhi keberlanjutan pelaksanaan pembangunan itu sendiri. Maju mundurnya suatu negara dan bangsa sangat ditentukan keunggulan kualitas dan daya saing SDM-nya. Telah terbukti bahwa

1 Manning, Chris. Labour Market Adjustment to Indonesia's Economic Crisis: Context, Trend, and Implications. Bulletin of Indonesian Economic Studies (BIES).Vol.36. No. 1. April 2000: p.105-136. ANU Canberra.

2Elizabeth, R. Remitansi Bekerja dari Luar Negeri dan Diversifikasi Usaha Rumah Tangga di Pedesaan.Tesis.IPB. Bogor: 2007

3 Sumaryanto, R. Elizabeth, S. Pasaribu, A. Taryoto, B. Sayaka. Studi Dinamika Penguasaan Lahan dan Kesempatan Kerja.PATANAS.Pusat Penelitian Sosial Ekonomi Pertanian. Bogor:1994 
meski dengan sumberdaya alam (SDA) terbatas, namun dengan keunggulan SDMnya, suatu negara mampu mencapai kesejahteraan yang tinggi.

Perbaikan dan peningkatan kualitas SDM bersifat multi dimensi, baik pendidikan, ketrampilan, kesempatan kerja dan berusaha, maupun gizi dan kesehatan. Faktor-faktor ini juga yang harus dikembangkan untuk memperkuat gerakan gender dalam kebijakan pembangunan pertanian. Semuanya ini berkaitan erat dengan peran, tugas, dan fungsi serta kedudukan perempuan dalam strategi pembangunan pertanian melalui upaya pemberdayaan perempuan tani di perdesaan. Tingkat adopsi inovasi teknologi terhadap kaum perempuan relatif rendah. Untuk itu, Badan Litbang Pertanian membentuk tim inti untuk meningkatkan kapasitas para peneliti dan penyuluh dilingkupnya melalui program Sosialisasi dan Pelembagaan Analisis Sosial Ekonomi dan Gender (Socio-economics and Gender Analysis, SAGA).

Dengan penerapan adopsi inovasi yang lebih partisipatif, salah satunya melalui SAGA, terjadi peningkatan peran Gender dalamstrategi kebijakan pembangunan. Tulisan ini bertujuan mengemukakan dan mengkaji berbagai aspek dan pemikiran tentang upaya dakwah dalam pemberdayaan perempuan tani untuk meningkatkan peran, fungsi dan kedudukan mereka sebagai pendukung strategi dalam kebijakan pembangunan pertanian.

\section{B. MAKNA PERAN DAN POTENSI SERTA PELUANG}

Peran dan kedudukan merupakan dua aspek penting dalam hubungan sosial masyarakat. Peran merupakan perilaku individu dalam struktur sosial, dan merupakan aspek dinamis dari kedudukan, yang akhirnya akanmemberikan fasilitas tertentu sesuai denganperanan (role) tersebut. Sedangkan posisi mengindikasikan status sosial individu dimasyarakat. Dengan kata lain, kedudukan memberikan seseorang sebuah peran sebagai pola interaksi dalam bersosialisasi (bermasyarakat). Seseorang dinilai telah berperan, bilamana ia telah melakukan hak dan kewajibansesuai dengan statusnya.

Potensi yang dimiliki individu, akan berkaitan kemampuan mengakses dan memanfaatkan peluang yang ada. Masyarakat belum tentu memberi peluang yang seimbang meski seseorang mampu berperan sesuai peranannya. Bahkan masyarakat seringkali "terpaksa" membatasi peluang-peluang tersebut, seperti halnya yang terjadi pada kaum perempuan tani di perdesaan, karena keterkaitannya dengan potensi diri. Potensi membuat individu mampu berperan sesuai ataupun tidak dengan kedudukannya, karena merupakan daya dukung yang dimiliki secara khas oleh masing-masing individu.

Perubahan peran dan status perempuan umumnya disebabkan oleh perkembangan masyarakat dan wilayah di lingkungannya. Perubahan masyarakat 
tersebut makin dipacu oleh pertumbuhan ekonomi, akibat beralihnya sistem perekonomian dari sektor pertanian kesektor nonpertanian. Perubahan tersebut akan berdampak pada perubahan sosial dan budaya masyarakatnya. Perkembangan ekonomi dan sosial menimbulkan desintegrasi pembagian kerja antar Gender yang secara tradisional telah terbentuk sejak dulu.Pola kerja produktifyang baru antar ataupun lintas Gender mengarah pada diskriminasi pembagian kerja antar pria-perempuan. ${ }^{4}$ Selama masa transisi tersebut, bukan suatu keniscayaanbilamana berbagai fungsi produktif perempuan taniakan tercabut, yang berdampak pada perlambatan proses pertumbuhan pembangunan pertanian.

Dalam semua strata, terindikasi bahwa peran dan status perempuan dalam mengurus keberlangsungan rumah tangga lebih tinggi dibanding pria (kepala keluarga). Dominasi peran dan status tersebut menunjukkan tingginya potensi perempuan untuk mengendalikan dan mengarahkan rumah tangganya, ke arah lebih baik atau menjadi semakin buruk. Hal tersebut diperkuat bahwa pada kenyataannya lebih 50 persen dari total penduduk Indonesia adalah perempuan, dimana lebih dari 70 persen (atau sekitar 82,6 juta orang) berada di pedesaan dan 55 persen di antaranya hidup dari pertanian. 5

Data tersebut menunjukkan betapa besarnya potensi perempuan tani sebagai tenaga kerja yang perlu dioptimalkan pemanfaatannya. Meski demikian, dominasi peran perempuan tersebut berpeluang untuk mengalami perubahan, misalnya yang terjadi pada suami berstatus duda. Pada kondisi tersebut, mengatur dan menstabilkan kebutuhan rumah tangga akan dikendalikan oleh suami (meski terdapat anak perempuan yang sudah dewasa, saudara perempuan, ataupun ibu kandung/mertua sekalipun). Perbedaan status/posisi setiap anggota rumah tangga merupakan pengkajian diferensiasi peranan, berdasarkan perbedaan umur, jenis kelamin, status perkawinan, status/posisi sosial ekonomi, generasi, ataupun kekuasaan.

Perbedaan tersebut merupakan analisis struktural, yang sebagian besar disebabkan oleh alasan biologis dan sosial budaya lingkungan suatu rumah tangga. Teridentifikasi bahwa pada dasarnya perempuan memiliki peranan ganda dalam rumahtangga. Peran ganda kaum perempuan tersebut terimplikasi pada: (1) peran kerja sebagai ibu rumah tangga (mencerminkan feminimine role), meski tidak langsung menghasilkan pendapatan, secara produktif bekerja mendukungkaum pria (kepala keluarga) untuk mencaripenghasilan (uang); dan (2) berperan sebagaipencari nafkah (tambahan ataupun utama).

\footnotetext{
${ }^{4}$ Sajogyo, P.Peranan Perempuan dalam Perkembangan Ekonomi.Obor. Jakarta: 1984

5 Elizabeth, R..Peran Ganda Perempuan Tani sebagai Pelaku Usaha Mencapai Strategi Ketahanan Pangan Rumah Tangga Petani di Perdesaan. (sedang proses publish). Pusat Penelitian dan Pengembangan Tanaman Pangan. Bogor: Badan Penelitian dan Pengembangan Pertanian. Departemen Pertanian 2007
} 
Dalam pengembangan citra dan prospek perempuan abad XXI, terbentuk beberapa peran, antara lain: (1) Peran tradisi, yang menempatkan perempuan dalam fungsi reproduksi, dimana seratus persen hidupnya untukmengurusi keluarga, dan patron pembagiankerja jelas (perempuan di rumah/domestik, pria diluar rumah/publik); (2) Peran transisi, mengutamakan peran tradisi lebih dari yang lain,pembagian kerja menuruti aspirasi Gender, keharmonisan dan urusan rumah tangga tetap tanggungjawab kaum perempuan; (3) Dwi peran, memposisikan perempuan dalam dua dunia kehidupan (peran domestik-publik sama penting), dukungan moral dan perhatian suami menjadi pemicu ketegaran ataupun keresahan; (4)Peran egalitarian, kegiatan di publik menyita waktu dan perhatian perempuan, dukungan moral dan tingkat kepedulian pria sangat hakiki untukmenghindari konflik; (5) Peran kontemporer, merupakan dampak pilihan perempuan untuk mandiri dalam kesendirian. Jumlah golonganini belum banyak, namun berbagai benturan dari dominasi pria (yang belum tentu peduli pada kepentingan perempuan) akan meningkatkan populasinya. 6

Pada era globalisasi, peran transisi dan egalitarian diprediksi akan menimbulkan berbagai kondisi, yaitu: (1) dengan potensi dan kemampuan sebagai indikator penentu, keajegan penajaman peran pria dan perempuan akan memudar sehingga tidak jelas lagi pembedanya; (2) perempuan pekerja akan meningkat sedangkan pria pengangguranpun akan meningkat; (3) mobilitas sosial dan geografis memisahkan tempat tinggal suami-isteri, orang tua anak, sehingga keluarga menjadi tidak utuh. ${ }^{7}$ Berbagai kemungkinan tersebut mengindikasikan perempuan dan pria dapatberperan setara, sebagai pencari nafkah diberbagai bidang, kegiatan rumah tangga, dan dalam bersosialisasi di masyarakat. ${ }^{8}$

\section{DAKWAH TERHADAP PEREMPUAN DALAM KEBIJAKAN PEMBANGUNAN PERTANIAN}

Pembangunan pertanian di perdesaan telah menyebabkan gejala modernisasi dan urbanisasi serta berbagai perubahan sosial ekonomis dalam masyarakatnya. Terjadinya perubahan dalam sistem nilai sosial, normadan tatalaku, serta pola hubungan antar pria - perempuan. Ironisnya, keadaan tersebut juga menimbulkan terjadinya gejala desintegrasi dan diskriminasi dalam "pembagian kerja" antara pria dan perempuan di berbagai bidang. Hal ini secara empiris terlihat nyata pada keadaan tenaga kerja perempuan di berbagai

\footnotetext{
6Vitayala, A. S. Pemberdayaan Petani dan Kelembagaan Lokal dalam Perspektif Gender.Working Paper No. 50.Pusat Penelitian Sosial Ekonomi Pertanian. Bogor: 1995. ${ }^{7}$ Vitayala, A. S. Pemberdayaan Petani dan Kelembagaan Lokal dalam Perspektif Gender.Working Paper No. 50.Pusat Penelitian Sosial Ekonomi Pertanian. Bogor: 1995. 8Elizabeth, R..Peran Ganda Perempuan Tani sebagai Pelaku Usaha Mencapai Strategi Ketahanan Pangan Rumah Tangga Petani di Perdesaan. (sedang proses publish). Pusat Penelitian dan Pengembangan Tanaman Pangan. Bogor: Badan Penelitian dan Pengembangan Pertanian. Departemen Pertanian 2007
} 
bidang.Kondisi tersebut dapat dimaknai sebagai suatupermasalahan dan kendala dalam prosespembangunan, karena dikhawatirkan dapatmeminggirkan bahkan menghilangkan fungsiperan kaum perempuan dalam berproduktivitas, atau terjadinya marginalisasi peran perempuan.

Berbagai penelitian telah dilakukan dan berbagai laporannya telah dihasilkan, namun manfaatnya belum dinikmati kaum perempuan secara adil bahkan cenderung merugikan. ${ }^{9}$ Topik penelitianbervariasi meliputi alokasi, distribusi waktu dan tenaga kerja perempuan tani dalam aktifitas usaha tani, tingkat pengambilan keputusan, pemasaran hasil, income generating activities, dan sebagainya. Di sektor pertanian, perempuan yang turut bekerja di usahatani, tidak dianggap berprofesi sebagai "petani", tetapi hanya sebagai isteri (anggota keluarga) petani, yang wajib membantu segala pekerjaan suami (petani). Pria dan perempuan di perdesaan, layaknya kehidupan manusia, bersama-sama berdampingan bekerja di usahatani mereka, namun kesenjangan perempuan tani masih tetap ada, terutama dalam menggali potensi dan kemampuan mereka.

Dampaknya adalah terjadinya marginalisasi kaum perempuan tani, dimana kaum perempuan tani selalu tertinggal dibanding kaum pria. Perencanaan pembangunan pertanian di masalalu, bukan mustahil secara tidak sengaja telah mengabaikan peran kaum perempuan tani tersebut.10 Keteledoran tersebut menyebabkan posisi kaum perempuan makin terjepit dan terkungkung dalam dimensi keterbatasan. Secara internal, keterbatasan perempuan tercermin pada lebih rendahnya pendidikan, ketrampilan, rasa percaya akan kemampuan dan potensi diri. Secara eksternal, keterbatasan tersebut tercermin pada lebih rendahnya akses perempuan menangkap berbagai peluang di luar rumah tangganya.

White dan Hastuti ${ }^{11}$ melihat hubungan pria dan perempuan dalam masyarakat agraris sebetulnya mencerminkan: Pertama, kedudukan yang "berbeda tapi setara", dimana pria-perempuan berperan untuk kepentingan bersama dan saling melengkapi. Pemisahan peran dan pengaruh antar Gender bersifat komplementer, dalam upaya mencapai tujuan bersama, yaitu kesejahteraan dalam rumahtangga dan masyarakat. Meski diakui dan dibenarkan, serta dianut dalam berbagai program pembangunan dan berbagai ideology atau norma masyarakat, namun implementasinya bahkan bertolak belakang. Manfaat terbesarnya hanya dinikmati oleh satu jenis kelamin saja (pria). Kedua, kedudukan yang "berbeda dan tidak setara", merupakan dua pandangan yang saling

${ }^{9}$ Siwi, dan Manwan.Women in Rice Farming Activities in Indonesia. 22nd Asian Rice Farming System Working Group Meeting, Beijing, China: 1991

${ }^{10}$ Elizabeth,Peran Ganda Perempuan Tani sebagai Pelaku Usaha Mencapai Strategi Ketahanan Pangan Rumah Tangga Petani di Perdesaan. (sedang proses publish). Pusat Penelitian dan Pengembangan Tanaman Pangan. Bogor: Badan Penelitian dan Pengembangan Pertanian. Departemen Pertanian 2007

${ }^{11}$ Hastuti, E. L. Pemberdayaan Petani dan Kelembagaan Lokal dalam Perspektif Gender.Working Paper.No.50 Pusat Penelitian Sosial Ekonomi Pertanian. Bogor: 2004 
bertentangan, yang mencerminkan "kekuasaan perempuan nyata tapi tersembunyi", dan terdapatnya "penundukkan (intimidasi/penindasan) perempuan nyata tapi tersembunyi".

Berbagai keterbatasan yang mencerminkan marginalisasi perempuan tersebut terlihat dalam mengakses pendidikan, kesempatan kerja dan berusaha serta inovasi teknologi, diskriminasi tingkat upah, jenis dan nilai pekerjaan (bekerja pada lapisan terbawah), pekerjaan yang tersegragasi oleh gender, keterbatasan akses perempuan buruh ataupun pengusaha dibanding pria, nilai status social pekerja perempuan ("lupa kodrat" bahwa perempuan seharusnya hanya mengurus rumah tangga), ketidakhomogenan perempuan dalam keterlibatannya di sektor nonpertanian, ketertinggalan perempuan dalam penentuan dan pengambilan keputusan, dan berbagai dimensi lainnya. Padahal, dalam era globalisasi sekarang ini, daya saing ekonomi semakin rumit, kesulitan mendapat pekerjaan semakin terbatas dan tingginya kompetisi kesempatan kerja dan berusaha, dan bentuk-bentuk keluarga semakin kecil (dampak rekayasa dan desiminasi inovasi alat kontrasepsi).

Bias Gender di pertanian dan perdesaan, tidak terlepas dari perspektif klasik dalam cara memandang perempuan tani yangtimpang dan diskriminatif dengan kewajibanyang mengungkung dan menjebak mereka didalamnya. Nuansa klasik dari ketertindasankaum perempuan tani di tengah kerasnya kehidupan di sektor pertanian merupakan isu berdimensi Gender di sektor tersebut. Disamping itu, peran ganda yang mereka lakoni juga mencerminkan ketertindasan kaum perempuan; karena selain sebagai ibu rumah tangga (sektor domestik), mereka juga dituntutdapat mencari nafkah (sektor publik) untuk mengurangi beban ekonomi dan kehidupanrumah tangga. Tata nilai dan adat istiadat sangat berperan dalam membicarakan peran, khususnya peluang dan potensi perempuan tani disektor pertanian.Penetrasi teknologi baru (bibit unggul, huller/tresher, mekanisasi pengolahan lahan, dan herbisida) telah mengurangi dan menggeser kesempatan kerja perempuan tanidi perdesaan.

Kebijakan pembangunan pertanian berdimensi Gender, antara lain meliputi: (1)legitimasi peranan perempuan tani dengan berbagai aspeknya; (2) terdapatnya pemahaman yang lebih baik terhadap peran perempuan dan pria dalam aktivitas produksi; (3) minimnya identifikasi kebutuhan perempuan perdesaan dalam pembangunan pertanian akibat keterbatasan pemahaman petugas lapang akan Gender, tujuan dan analisisnya; 4) perencana dan pengambil kebijakan belum menganggap isu Gender sebagai masalah yang perlu dikaji; (5)nilai sosial budaya yang kurang mendukung keberadaan perempuan tani yang mengakibatkan pembuat kebijakan menjadi "bias Gender", sehingga terjadi pembatasan kesempatan danpeluang perempuan tani untuk mengakses berbagai sumberdaya pertanian (fasilitas kredit). 


\section{DAKWAH UNTUK PEMBERDAYAAN PEREMPUAN}

Selain dari tingginya potensi dan peluang perempuan sebagai tenaga kerja,12 besarnya harapan untuk peran perempuan tani juga tercermin dari makin rumit dansulitnya ekonomi rumah tangga petani di perdesaan karena makin sempitnya lahan usahatani. Semakin terbatasnya lahan usaha tani produktif merupakan dampak tingginya konversi lahan pertanian produktif ke penggunaannonpertanian, sebagai konsekuensi ledakan penduduk dan peningkatan nilai ekonomi akibat tingginya permintaan lahan untuk prasarana industri, perdagangan serta pemukiman. Di sisi lain, laju pergeseran ekonomi sektoral relatif lebih cepat dibanding laju pergeseran tenaga kerja; dimana titik balik untuk aktivitasekonomi di Indonesia lebih dulu tercapai dibanding titik balik penggunaan tenaga kerja(labor turning point). ${ }^{13}$

Keterbatasan kesempatan kerja dan berusaha menunjukkan betapa perlu danpentingnya pemberdayaan kaum perempuan agarmampu menghasilkan SDM dalam rumahtangga sebagai tenaga kerja dan generasipenerus yang berkualitas dan berdaya saing tinggi. Dakwah Pemberdayaan merupakan serangkaian upaya untuk meningkatkan kemampuan dan memperluas akses terhadap suatu kondisi untuk mendorong kemandirian yang berkelanjutan (tanggap dan kritisterhadap perubahan) serta mampu berperanaktif dalam menentukan nasibnya sendiri, melalui penciptaan peluang yang seluasluasnyaagar mampu berpartisipasi. ${ }^{14}$ Dengan mengimplementasi pemikiran Sumodiningran ${ }^{15}$, sedikitnyaada tiga aspek yang dicakup dalam memaknaipemberdayaan perempuan, yaitu: (1) menciptakankondisi yang kondusif yang mampu mengembangkan potensi perempuan; (2) memperkuat potensi (modal) sosial perempuan demi meningkat mutu kehidupannya; (3) mencegah dan melindungi perempuan, serta mengentaskan ketertindasan dan kemarginalan segala bidang kehidupan mereka.

Upaya menciptakan suasana/iklim kondusif yang memungkinkan suatu potensidapat berkembang dan menguat dengan cara:(1) mendorong, memotivasi dan membangkitkan kesadaran akan potensi yang dimiliki;(2) menciptakan aksesbilitas terhadap berbagai peluang yang menjadikannya semakinberdaya; dan (3) diperlukan tindakan perlindungan terhadap potensi sebagai bukti keberpihakan yang mencegah dan membatasi persaingan yang tidak seimbang dan

12BPS.Data Kependudukan. Badan Pusat Statistik. Jakarta: 1990-2006.

13 Manning, Chris. Labour Market Adjustment to Indonesia's Economic Crisis: Context, Trend, and Implications. Bulletin of Indonesian Economic Studies (BIES).Vol.36. No. 1. April 2000: p.105-136. ANU Canberra. Jakarta: 1999.

${ }^{14}$ Sumodiningrat, G. Pemberdayaan Masyarakat dan Jaring Pengaman Sosial. Gramedia,

${ }^{15}$ Sumodiningrat, G. Pembangunan Daerah dan Pemberdayaan Masyarakat. Bina Rena Pariwara, Jakarta:1997 
cenderungeksploitasi terhadap yang lemah oleh yangkuat. Pemberdayaan (empowerment) perempuan merupakan upaya penguatan terhadap ketidakberdayaan mereka agar mampu menolong diri sendiri, mandiri, serta mengembangkan semangat self-reliance-nya.

Terkait dengan pemberdayaan perempuan, peran dan potensi mereka sangat dibutuhkan, dan strategis kedudukannya serta mulia nilainya dalam mengatur dan mengurus sumberdaya keluarga, terutama anak-anak, dan sumberdaya material rumah tangga lainnya. Anak-anak merupakan faktor utama sumberdaya manusia, sebagai calon generasi penerus. Self-reliance perempuan, sebagai ibu rumahtangga, tercermin pada usaha memaksimalisasi kemampuan mereka mempersiapkan anak-anak untuk mampu memperoleh pekerjaan yang lebih baik dari orangtuanya kelak, melalui pembekalan pendidikan dan ketrampilannya, di samping pembinaan ahlak dan martabat mereka.

Pada kondisi tersebut, dengan memberi pendidikan yang terbaik untuk kaum perempuan, maka suksesnya suatu rumah tangga (terutama masa depan anak-anak/generasipenerus), sangat tergantung pada kemampuandan potensi memadai dari perempuan, sebagaiisteri dan ibu rumah tangga. Dengan kata lain,berkaitan dengan keberadaan dan ketersediaan sumberdaya manusia (generasi penerus)berkualitas dan berdaya saing tinggi di masadepan; maka strategi gender sangatlah logis danlayak dialiniasi dan diaktualisasi, serta diposisikan di tempat utama dalam setiap strategi kebijakan pembangunan. Hal tersebut dapat dicapai salah satunya melalui pemberdayaan (empowerment) mereka dalam semua sektor. Oleh karena itu diperlukan inovasi dan adopsi teknologi yang berkaitan dengan upaya peningkatan kemampuan dan potensi kaumperempuan.

Dakwah dalam memberdayaan perempuan menjadi strategi penting dalam peningkatan peran dan peluang perempuan tani. Dalam pembangunan pertanian, pemberdayaan perempuan tani merupakan proses transformasi yang lebih aplikatif untuk mampu menangkap berbagai perubahan alokasi sumbersumber ekonomi, distribusi manfaat, dan akumulasi dalam upaya meningkatkan produksi, pendapatan rumah tangga, serta adopsi dan penyebaran teknologi. Pemberdayaan perempuan juga merupakan upaya peningkatan dan pengaktualisasian potensi dirimereka agar lebih mampu mandiri dan berkarya, mengentaskan keterbatasan pendidikan dan ketampilan mereka, dan mengentaskan mereka dari ketertindasan akibat perlakuan yang diskriminatif dari berbagai pihak dan lingkungan sosial budaya.

Pemberdayaan dapat dilakukan melalui pengembangan pembinaan dan peningkatan efektivitasnya, baik sebagai anggotarumah tangga maupun sebagai pengusaha mandiri, perlindungan terhadap tenaga kerja perempuan, meningkatkan efektifitas penyuluhandan pelatihan, perbaikan regulasi, fasilitas, dantingkat upah, pelatihan dan pembinaan ketrampilan industri rumah tangga, 
serta kesempatan kerja agar berimbang antar Genderdan mengikutsertakan mereka dalam segala kegiatan pembangunan. Pemberdayaan perempuan di segala bidang sangat diperlukan mendukung strategi gender pada kebijakan pembangunan pertanian.

\section{E. Strategi Dakwah Pemberdayaan Perempuan Dalam Kebijakan Pembangunan Pertanian}

Kajian dan pemahaman tentang Genderberhubungan erat dengan perlakuan, gagasan, konstruksi budaya, bahkan teknologi bias Gender. Perbedaan perilaku antara pria dan perempuan, selain disebabkan faktor biologis, sebagian besar justru terbentuk melalui proses sosial dan kultural. ${ }^{16}$ Kesadaran Gender berarti pria dan perempuanbekerja sama dalam suatu keharmonisan caramemiliki kesamaan dalam hak, tugas, posisiperan dan peluang (kesempatan), dan menaruh perhatian terhadap kebutuhan-kebutuhanspesifik yang melengkapi dan memperkuatnya. ${ }^{17}$ Gender merupakan pemilahanperan dan hubungan antara pria dan perempuan,bagian konsepsi pengorganisasian "pembagian kerja", baik dalam keluarga, rumah tangga, masyarakat luas, dan merupakan bagian darikehidupan sosial budaya, dimana keberbedaan keduanya adalah sebuah keniscayaan.

Pemilahan tersebut dilakukan melalui: (1) Teori kodrat alam (nature). Berbagai perbedaan pria-perempuan berdasarkan alat tubuh dan sifat yang melekat di keduanya secara alami maupun kewajiban kodrati. Pekatnya nilai alami perempuan dalam status sosial masyarakat, menyebabkan penilaian punishment pada perempuan yang beraktifitas di luar rumahtangga, karena dianggap menyalahi kodrat.Sangsi dan pikiran-pikiran seperti ini dinilai "mengada-ada" oleh $^{18}$, karena apabila terjadi ketidak seimbangan atas dasar perbedaan hak, maka produktivitas masyarakat akan terhambat, sehingga akan mengakibatkan perlambatan laju pembangunan19; (2) Teori kebudayaan (culture), mengkaji perbedaan berdasarkan anatomi dan fungsi bagian tubuh keduanya yang berkonsekuensi pada perangai psikologisnya; (3) Teori fungsionalisme structural yang mengacu pada keharmonisan suatusistem sosial dan keharusan menjaga tertibsosial untuk mencapai keseimbangan dan ketenangan; dan (4) Teori psikoanalisis yangmengurai perbedaan melalui rasa ketidakpuasan perempuan

\footnotetext{
${ }^{16}$ Caplan.The Cultural Construction of Sexuallity.Jurnal Analisis Sosial.Edisi 4 Nopember 1996.AKATIGA. Bandung: 1978.

17Vitayala, A. S. Pemberdayaan Petani dan Kelembagaan Lokal dalam Perspektif Gender.Working Paper No. 50.Pusat Penelitian Sosial Ekonomi Pertanian. Bogor: 1995.

18Tjandraningsih, Mengidentifikasi Persoalan Perempuan dalam Analisis Gender dalam Memahami Persoalan Perempuan.Jurnal Analisis Sosial.Edisi 4 Nopember 1996.AKATIGA. Bandung: 1996.

${ }^{19}$ Elizabeth, R..Peran Ganda Perempuan Tani sebagai Pelaku Usaha Mencapai Strategi Ketahanan Pangan Rumah Tangga Petani di Perdesaan. (sedang proses publish). Pusat Penelitian dan Pengembangan Tanaman Pangan. Bogor: Badan Penelitian dan Pengembangan Pertanian. Departemen Pertanian 2007
} 
(kecemburuan) terhadap dampak kekurangan "alat" miliknya dibanding milikpria. Teori ini kurang layak dan agak fenomenal, sehingga jarang digunakan karena menuai banyak sanggahan.

Analisis Gender merupakan alat analisis konflik yang difokuskan pada ketidakadilan struktural yang disebabkan oleh Gender. ${ }^{20}$ Mengemukakan perlunya pendekatan JDP (Gender Dalam Pembangunan) danpendekatan WDP (Perempuan Dalam Pembangunan) dalam setiap program pembangunan. Aspirasi, kebutuhan, dan minat Gender, sehingga pengembangan perencanan dan implementasi program lebih banyak mencakup kebutuhan strategis Gender. Pendekatan WDP didesain untuk menjembatani kesenjangan priaperempuan dalam semua aspek pembangunan.Muncul dan berkembangnya berbagaigerakan perempuan dan disiplin tentang studiperempuan, mempengaruhi perkembangan teoriteori feminis yang berkaitan erat dengan isu Gender. Teori feminis menekankan institusi dantindakan sosial yang meliputi tradisi feminisliberal, feminisme Marxis, feminisme radikal, feminisme sosial, serta dua konsep yang lebihbaru dan sedang "booming" penggunaannya,yaitu: feminisme kultural dan feminisme struktural, meskipun keduanya memiliki keterbatasan dalam wacananya. Gender dapat berubah antar waktu, tempat dan kelas sosial ekonomi masyarakat, namun jenis kelamin (sex) tidak berubah. ${ }^{21}$

Perbedaan Gender (jenis kelamin) disebabkan oleh alasan biologis dan lingkungansosial budaya suatu rumah tangga, dianalisissecara struktural dan merupakan pengkajiandiferensiasi peranan, meliputi perbedaanumur, generasi, status sosial ekonomi, ataupun kekuasaan (power) (Paris, 1987). Pola nafkah ganda yang pernah dipopulerkan olehSajogyo, telah membuktikan manfaat positif peran ganda perempuan, bukan hanya cerminan marginalisasi kaum perempuan saja. Pola nafkah ganda berupa: (1) pencari nafkah tambahanatau utama (income earning work) dalam upaya meningkatkan pendapatan rumah tangga;maupun (2) sebagai ibu rumah tangga (mencerminkan feminimine role), yang meski tidak langsung menghasilkan pendapatan (uang),namun secara produktif bekerja mendukungkaum pria (kepala keluarga) untuk mencaripenghasilan.

Pekerjaan mengurus dan mengatur rumah tangga (domestic work), meski tidakmemberi penghasilan langsung, pada dasarnya merupakan pekerjaan yang ekonomis produktif. Hal ini terbukti bilamana pelaksanaannya digantikan (diintegrasikan) pihak jasatenaga kerja bayaran (paid worker) yang diberi imbalan, berupa gaji (upah) sesuai ketentuanyang berlaku dalam masyarakat atau pemerintah (UMR), atas pekerjaannya mengurus suaturumah tangga. Sebagai anggota rumah tanggapetani, perempuan tani berperan aktif dalam mem bantu

\footnotetext{
${ }^{20}$ Vitayala, A. S. Pemberdayaan Petani dan Kelembagaan Lokal dalam Perspektif Gender.Working Paper No. 50.Pusat Penelitian Sosial Ekonomi Pertanian. Bogor: 1995.

${ }^{21}$ Fakih, M. Gender sebagai Alat Analisis Sosial; dalam: Analisis Gender dalam Mema hami Persoalan Perempuan. Jurnal Analisis Sosial. Edisi 4 Nopember AKATIGA. Bandung: 1996.
} 
aktivitas usahatani dan mencari nafkahdi subsektor off dan non farm. Semakin rendah tingkat ekonomi suatu rumah tangga petani, makin besar curahan tenaga dan waktu perempuantani dalam upaya memperoleh pendapatan keluarga. ${ }^{22}$

Sumbangan pendapatan (nilai ekonomi) yang diperoleh kaum perempuan tani dari polanafkah ganda terbukti cukup besar dalam penghasilan keluarga.Penghasilan tersebut diperoleh baik dengan bekerja di lahan usahatani sendiri, sebagai buruh tani, maupun sebagai tenaga kerja di luar sektor pertanian. Meski demikian besar peran dan sumbangan kaum perempuan, belum memprioritaskan pemberdayaan perempuan, kesetaraan dan keadilan gender, serta kesejahteraan dan perlindungan anak. ${ }^{23}$

Gender pembangunan bertujuan agar pelaksanaanprogram-program pembangunan dapat mempertimbangkan kesempatan dan akses perempuan terhadap program pembangunan, yaitu dengan terciptanya kendali serta manfaat bagi perempuan.Dengan demikian, diperlukan pembinaan peran perempuan tani agar mampu meningkatkan peran dan potensi mereka, terutama produktivitasnya melalui pemberdayaan mereka di segala bidang.

\section{F. KESIMPULAN}

Marginalisasi kaum perempuan tercermin pada ketertindasan dan perlakuan diskriminatif"pembagian kerja" (jenis kerja, waktu/tenagayang tercurah, dan tingkat upah), yang perempuan terima dari berbagai kalangan/lingkungan.Ketertindasan tersebut hendaknya dinilai secara positif dan inovatif dengan memaknainya sebagai tantangan dan peluang.Perempuan sebagai ibu rumah tangga merupakan peran danpotensi yang memiliki peluang sangat strategis dalam menghasilkan SDM (anak-anak sebagai generasi penerus) yang berkualitas dan berdaya saing tinggi.Selain itu, kontribusi perempuan sebagai pencari nafkah dapat diartikan sebagai peluang untuk meningkatkan potensi dan produktivitas mereka sebagai tenaga kerja,dalam upaya meningkatkan pendapatan, khususnya rumah tangga petani di perdesaan.

Dakwah dalam memberdayaan perempuan merupakan proses transformasi yang lebih aplikatif untuk menangkap berbagai perubahan alokasi sumber-sumber ekonomi, distribusi manfaat, dan akumulasi untuk meningkatkan produksidan pendapatan rumah tangga. Pemberdayaan perempuan di segala bidang, sejalan denganupaya mendukung strategi pengarusutamaan Gender dalam pembangunan pertanian. Diperlukan pemberdayaan (empowerment) perempuan

${ }^{22}$ Elizabeth, R. Peran Ganda Perempuan Tani sebagai Pelaku Usaha Mencapai Strategi Ketahanan Pangan Rumah Tangga Petani di Perdesaan. (sedang proses publish). Pusat Penelitian dan Pengembangan Tanaman Pangan. Bogor: Badan Penelitian dan Pengembangan Pertanian. Departemen Pertanian 2007

${ }^{23}$ Hastuti, E. L. Pemberdayaan Petani dan Kelembagaan Lokal dalam Perspektif Gender.Working Paper.No.50 Pusat Penelitian Sosial Ekonomi Pertanian. Bogor: 2004 
sebagai upaya untuk peningkatan dan pengaktualisasian potensi diri mereka agar lebih mampu mandiri dan berkarya, mengentaskan mereka dari keterbatasan pendidikan dan ketrampilan, dan ketertindasan akibat perlakuan yang diskriminatif dari berbagai pihak dan lingkungan sosial budaya.

Selain dengan materi, metode dan media dalam dakwah, diperlukan pula peningkatan daya serap dan adopsi teknologi sebagai strategi pemberdayaan perempuan dalam segala proses pembangunan melalui peningkatan pendidikan, pembinaan dan pelatihan ketrampilan, teknologi tepatguna dan inovatif. Pemberdayaan perempuan dicapai melalui perlindungan terhadap tenaga kerja perempuan, meningkatkan efektifitas penyuluhan dan pelatihan, perbaikan regulasi, fasilitas, dan upah, serta kesempatan kerja agar berimbang antar Gender sebagai insentif dan keberpihakan terhadap kaum perempuan tani diperdesaan. 


\section{DAFTAR PUSTAKA}

BPS, Data Kependudukan. Badan Pusat Statistik. Jakarta: 1990-2006

Caplan, The Cultural Construction of Sexuallity. Jurnal Analisis Sosial. Edisi 4 Nopember 1996. Bandung: AKATIGA, 1978.

Elizabeth, R. Remitansi Bekerja dari Luar Negeri dan Diversifikasi Usaha Rumah Tangga di Pedesaan.Tesis.IPB. Bogor: 2007

Elizabeth, R. Peran Ganda Perempuan Tanisebagai Pelaku Usaha Mencapai StrategiKetahanan Pangan Rumah Tangga Petanidi Perdesaan. (sedang proses publish).Pusat Penelitian dan Pengembangan Tanaman Pangan.Bogor : 2007. Badan Penelitiandan Pengembangan Pertanian. Departemen Pertanian.

Fakih, M. Gender sebagai Alat Analisis Sosial; dalam: Analisis Gender dalam Memahami Persoalan Perempuan, Jurnal Analisis Sosial. Edisi 4 Nopember 1996, Bandung: AKATIGA, 1996.

Hastuti, E. L.Pemberdayaan Petani dan Kelembagaan Lokal dalam Perspektif Gender, Working Paper.No.50 Pusat Penelitian Sosial Ekonomi Pertanian. Bogor: 2004

International Rice Research Institute (IRRI). Woman in Rice Farming Systems: An Operational Research and Training Program. Training and Workshop Gender Analysis. November 1993. IRRI. Manila. Philippines: 1987

Manning, Chris. Labour Market Adjustment toIndonesia's Economic Crisis: Context,Trend, and Implications. Bulletin of Indonesian Economic Studies (BIES).Vol.36.No. 1. April ANU Canberra: 2000

Paris, T. R. Women in Rice Farming System: A Preliminary Report of an Action Research Program in Sta. Barbara. Pangasinan.IRRI. Los Banos. Phillipines: 1987

Sajogyo, P. Peranan Perempuan dalam Perkembangan Ekonomi.Obor. Jakarta: 1984

Sajogyo, P. Konsepsi dan Metodologi dalam Studi Peranan dan Status Sosial Perempuan dalam Keluarga, Rumah Tangga, dan Masyarakat; dalam Peranan Perempuan dalam Usahatani. Prosiding Lokakarya GenderAnalysis dalam Sistem Usahatani.Bogor, Pusat Penelitian dan Pengembangan Tanaman Pangan. Bogor: 1992

Siwi, S. S., dan I. Manwan. Women in RiceFarming Activities in Indonesia. 22nd AsianRice Farming System Working GroupMeeting, Beijing, China: 1991

Siwi, S.S., F. Sulaiman, E. Basuno, R. N. Suhaeti,Rochlini and C. P. Pelzer.Socioeconomic \& Gender Analysis (SAGA) inAgricultural Research and DevelopmentProgramme. SAGA Core Team, AARD. Jakarta: 2000 
Sumaryanto, R. Elizabeth, S. Pasaribu, A. Taryoto, B. Sayaka. Studi Dinamika Penguasaan Lahan dan Kesempatan Kerja.PATANAS. Pusat Penelitian Sosial Ekonomi Pertanian, Bogor: 1994

Sumodiningrat, G, Pembangunan Daerah danPemberdayaan Masyarakat. Bina Rena Pariwara, Jakarta: 1997

Sumodiningrat, G. Pemberdayaan Masyarakat dan Jaring Pengaman Sosial. Gramedia, Jakarta: 1999

Tjandraningsih, Mengidentifikasi Persoalan Perempuan dalam Analisis Gender dalam Memahami Persoalan Perempuan, JurnalAnalisis Sosial.Edisi 4 Nopember 1996.AKATIGA. Bandung: 1991

Vitayala, A. S.Posisi dan Peran Perempuan dalam Era Globalisasi dalam E. L. Hastuti, 2004.Pemberdayaan Petani dan Kelembagaan Lokal dalam Perspektif Gender.Working Paper No. 50.Pusat PenelitianSosial Ekonomi Pertanian. Bogor: 1995 